Available online at https://jurnal.iainponorogo.ac.id/index.php/eltall

\title{
THE CORRELATION BETWEEN STUDENTS' SELF CONFIDENCE AND THEIR SPEAKING SKILL AT THE TWELFTH GRADE OF SMA N 2 BUKITTINGGI
}

\author{
Riva Silvia Sari; Merry Prima Dewi \\ Institut Agama Islam Negeri Bukittinggi \\ rivasilviasari01@gmail.com
}

\section{Abstract}

The design of this research was correlational research. This research aimed to find out the correlation between students' self-confidence and speaking skills at the twelfth grade of SMA N 2 Bukittinggi. The background of this research was there were several problems related to students' self-confidence, and those problems were contrary to the theory. The population of this research was all of the twelfth-grade students of SMA N 2 Bukittinggi in the academic years of 2020/2021, which consists of 8 classes. The sample was 28 students taken by simple random sampling technique. The research results showed that there is a correlation between students' self-confidence and their speaking skill. The researcher found that the coefficient of correlation between students' self-confidence and their speaking skill was 0,286. There was a positive correlation and significance. It means that Ho is accepted. Thus, there is a positive correlation between students' self-confidence and speaking skills at the twelfth grade of SMA N 2 Bukittinggi.

\section{Keywords: Correlation, Self Confidence, Speaking Skills}

\section{INTRODUCTION}

There are four language skills that have to be mastered if we want to learn English; they are listening, speaking, reading, and writing. One of the main skills in English is speaking. Speaking is a productive auditory or oral skill. It consists of producing systematic oral utterances to transfer meaning (Nunan, 2004, p.48). It means that speaking is verbal communication that used mouth to speak and ear to listen to convey information or meaning. Furthermore, speaking is two or more people communicate with each other about something that they think interesting to talk and relate to the situation (Luoma, 2004, p.20). Speaking can happen if there are two or more people talk to each other. They talk about something that they need to talk appropriately with the condition. Otherwise, speaking is people who know a language as a speaker of a language, and speaking involved all people who know a language not only foreign language but also learners who have interested to learn English speaking (Ur, 1991, p.120). 
Based on the researcher's preliminary research by conducting observation at the eleventh grade of SMAN 2 Bukittinggi on February $11^{\text {th }}$ 2020 through observation, the researcher found some problems in the speaking. Some of the students chose to be silent while learning speaking. Some of the students chose to be silent while learning speaking. Unfortunately, among all students, only a few students can answer questions given by the teacher. Besides, the researcher found few students fell asleep, the students who speak with their friends, and the students who do other activities. Conversely, there were some students observed and followed the lesson, answered the teachers' question, and speak English.

Furthermore, the researcher interviewed an English teacher on February $12^{\text {th }} 2020$. Based on that interview, the teacher said that some students chose to be silent when the teacher asked them to speak English. Otherwise, the teacher mentioned that the students' interest in English was less. On the contrary, there were some students capable to speak English even though it was not perfect. In addition, the researher also interviewed some students on February $12^{\text {th }} 2020$. Some students mentioned that they had lack self-confidence. Lack of students' self-confidence was caused by several factors. The factors were; the students felt anxious or nervous to speak English because they had difficulties thinking about English vocabulary, they didn't know how to pronounce a word or a vocabulary in English because they think that vocabulary in English is difficult to pronounce, they had difficulties deciding any tenses in English, the students felt shy to speak English. Briefly, there were some students lack selfconfidence and the students had self-confidence in speaking.

As mention previously, there is another aspect to speak, the important one is what people thinking and feeling. This involves; our inner voice, our level of self-confidence, our attitude, values, perceptions, and prejudices (Rowson, 2005, p.15-16). The psychological aspects can influence the students to speak English. One of the aspects is level of self-confidence. self-confidence is a belief that someone who can do a task is based on whether or not they have been able to present in the past. Someone who has self-confidence belief that they will be able to recover, leave negative things, and move to positive experiences (McPheat, 2010, p.14). Self-confidence can influence someone whether they have negative thinking about their own-self or they think positively to themselves. Moreover, they can leave negative things that make them lack confidence mainly speaking. They are able to move to positive experiences. Additionally, self-confidence is one skill that has precious to obtain and not to be underestimated (Murray, 2006,p.53).

In speaking, students should have self-confidence mainly to speak English. self-confidence significantly influences the learner's readiness to communicate in a foreign language (Intrye, 2004, p.199). Self-confidence 
BL'TALL (ENGLISH IANGUAGE 'TIACHING, APPLIED LINGUIS'IICS

ANI) II'TIRA'TURE)

Vol. 2 No. 2, 2021

Available online at https://jurnal.iainponorogo.ac.id/index.php/eltall

influenced the students when they want to communicate in English. many people are nervous about speaking up in group discussions. They are afraid about what they say looking bad or others will judge them stupid. People should improve their public speaking skills. Then, they will feel more confident and they can easily speak in sharing opinions and ideas in front of other people (McPheat, 2010, p.36-37). Many people are nervous about speaking up in group discussions. They are afraid about what they say looking bad or others will judge them stupid. People should improve their public speaking skills. Then, they will feel more confident and they can easily speak in sharing opinions and ideas in front of other people.

\section{METHOD}

This research is a correlational research. correlational research involves measuring the relationship between two or more variables. Correlational research often measures many different variables (Lodico et al, 2010, p.273). The researcher used quantitative research to measure it because the researcher wanted to know the degree of relationship between the two variables. To collect the data, the researcher used a personality test and retelling a story or news event. Otherwise, to analyze the data, the researcher used two variables for finding the correlation between students' self-confidence and speaking skills. The population of this research was all of the twelfth grade students in SMA N 2 Bukittinggi, which consists of eight classes.

\section{FINDINGS AND DISCUSSION}

In finding, the researcher shows about the correlation finding and the interpretation of the data that are collected through students' self-confidence and speaking skill. 
Available online at https://jurnal.iainponorogo.ac.id/index.php/eltall

\section{Description of the Data}

Table 1.1

Data Distribution

Statistics

\begin{tabular}{|l|r|r|}
\hline & \multicolumn{2}{|c|}{ SELF } \\
& CONFIDENCE & \multicolumn{2}{|c|}{$\begin{array}{c}\text { SPEAKING } \\
\text { SKILL }\end{array}$} \\
\hline & Malid \\
g & 28 & 28 \\
Mean & 0 & 0 \\
Median & 34.71 & 19.53 \\
Mode & 34.21 & 19.94 \\
Std. Deviation & 22 & 21 \\
Minimum & 10.026 & 3.478 \\
Maximum & 22 & 13 \\
Sum & 55 & 27 \\
\hline
\end{tabular}

a. The Description Data of Students' Self-confidence

In collecting the data for variable $X$, the researcher used the personality test that consisted of 25 questions or statements. It has three different options and different interpretations depend on the student's total points. In this test, the researcher gave 2 points for every ' $b$ ' answer, 1 point for every ' $c$ ', and 0 points for every ' $a$ '. The theoretical data can be showed that mean; 34,71, median; 34,21, mode; 22, standard deviation; 10,02, minimum score; 22, maximum score; 55, and sum; 972.

b. The Description Data of Students' Speaking Skill

In collecting the data for variable $Y$, the researcher used the speaking test; retelling a story about the needle tree. Besides, scored interview was used as the scoring of speaking tests. The scoring of the speaking test included components: pronunciation, grammar, vocabulary, fluency, and comprehension. The theoretical data showed that mean; 19,53, median; 19,94, mode; 21, standard deviation; 3,47, minimum score; 13, maximum score; 27, and sum; 547. 
ISTALL (ENGLISH IANGUAGE 'TEACHING, APPLIED LINGUISTIICS

ANI) LI'TIRA'TURE)

Vol. 2 No. 2, 2021

Available online at https://jurnal.iainponorogo.ac.id/index.php/eltall

c. The Analysis of the Data

In this research, the data collected by using personality tests and speaking tests. The researcher was used statistical calculation to analyze the data which have been gotten. The researcher used the formula by using the Pearson Product Moment Correlation to find out the correlation.

Table 1.2

\section{Correlations}

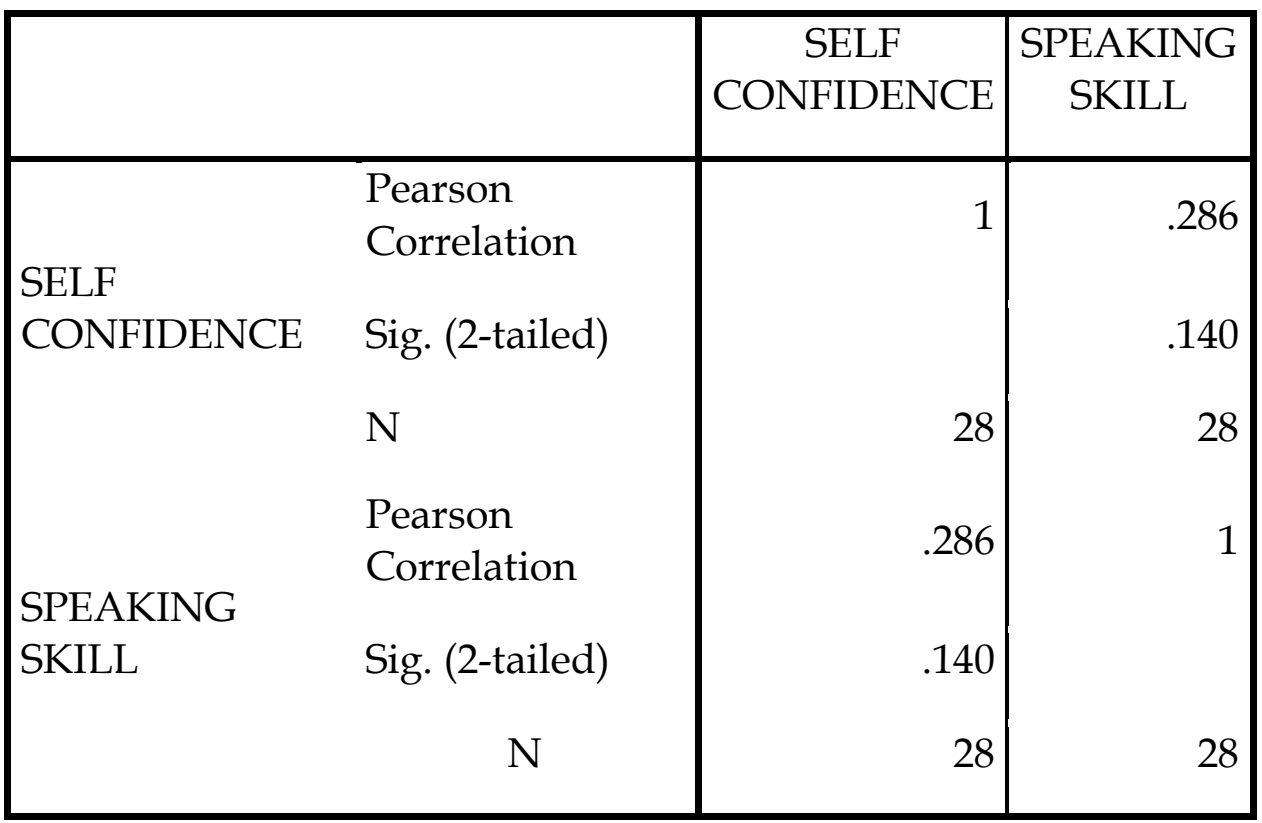

The table above showed the correlation coefficient $r=0,286$. It means that there was a positive relationship between self-confidence and speaking skills. Based on the interpretation of the Pearson Product Moment Correlation Coefficient between 0,20-0,40. Thus, there was a low correlation between two variables. To know the magnitude of the correlation between self-confidence and speaking skill, the researcher consults with the interpretation table below:

Table 1.3

Magnitude of Correlation

\begin{tabular}{|c|c|}
\hline Coefficient & Magnitude of Correlation \\
\hline $0,80-1,00$ & Very High \\
\hline $0,60-0,80$ & High \\
\hline $0,40-0,60$ & Sufficient \\
\hline $0,20-0,40$ & Low \\
\hline $0-0,20$ & Very Low \\
\hline
\end{tabular}


Available online at https://jurnal.iainponorogo.ac.id/index.php/eltall

Shortly, the correlation coefficient shows that the correlation between self-confidence and speaking skill was 0,286. This interpretation answers the third question in this research. Based on the interpretation table above, 0,286 "has a low" correlation because it was between 0,20-0,40. In conclusion, the magnitude of the correlation between self-confidence and speaking skill was low.

\section{Testing Hypothesis}

There were two hypotheses; Ha: there is a correlation between students' self-confidence and their speaking skill. The second hypothesis is Ho: there is no correlation between students' self-confidence and speaking skills. To consult with the r-table, the researcher has to determine the degrees of freedom (df) and the significant alpha value (b). The degrees of freedom in this research is $\mathrm{N}-2=28-2=26$. After that, the researcher uses a significant alpha value $(\mathfrak{b})=0,05$. To determine whether the researcher will accept or reject the hypothesis, the researcher uses the formulation below:

If $r_{x y}>r_{t a b}$, so Ha is accepted and Ho is rejected

If $r_{x y}<r_{t a b}$, so Ha is rejected and Ho is accepted

The researcher consults to $\mathrm{r}$-table with significant alpha value $(\mathrm{p})=0$, 05 and $\mathrm{df}=26$. Based on the $\mathrm{r}$-table, it is obtained 0,3739, and the researcher has $r_{x y}=0,286$. It means that $r_{x y}$ score is smaller rather than r-table score.

If $r_{x y}<r_{t a b}$, so Ha is rejected and Ho is accepted

$0,286<0,3739$, so Ha is rejected and Ho is accepted

Shortly, Ho is accepted and Ha which states that there is a significant correlation between students' self-confidence and speaking skill is rejected.

\section{CONCLUSION}

In this research, it correlates the students' self-confidence score and their speaking skill score. Based on the research question about the correlation between students' self-confidence and their speaking skill, it can be concluded:

1. The Ha or alternative hypothesis of this research is rejected. It can be said that there is a correlation between students' self-confidence and their speaking skill. The result is obtained after the researcher consulted $r_{x y}$ score to r-table. $r_{x y}$ score that has been gotten by the researcher is 0,286 whereas r-table score on alpha 0,05 is 0,3739 . It means that $r_{x y}$ score is smaller than r-table score. As a result, $\mathrm{Ha}$ is rejected and Ho is accepted.

2. The results of this research have a positive direction between students' self-confidence and their speaking skill. It can be proven by the result which has been gotten by the researcher as much $+0,286$. It shows that between students' self-confidence and their speaking skill is in a positive line direction. Shortly, if the students have high self-confidence, they have 
ILITALL (ENGLISH IANGUAGE 'TEACHING, APPIIED LINGUIS'IICS

ANI) II'TIRA'TURE)

Vol. 2 No. 2, 2021

Available online at https://jurnal.iainponorogo.ac.id/index.php/eltall

high skill in speaking. Conversely, if the students have low selfconfidence, they have low skill in speaking.

3. The magnitude of the correlation between students' self-confidence and their speaking skill is low. It can be proven by the coefficient of correlation is on category $0,20-0,40$. It means that there is a low correlation between students' self-confidence and their speaking skill at the twelfth grade of SMA N 2 Bukittinggi.

\section{REFERENCES}

Arikunto, Suharsimi. (2013). Dasar-Dasar Evaluasi Pendidikan Edisi Revisi. Jakarta: Bumi Aksara.

Lodico, G. Marguerite Dean, Katherine. (2010). Methods in Educational Research From Theory to Practice Second Edition. US: Jossey-Bass A Wiley Imprint.

Luoma, Sari. (2004). Assessing Speaking. New York: Cambridge University Press.

Mcpheat, Sean. (2010). Personal Confidence E Motivation. MTD Training: MTD Training \& Ventus Publishing ApS.

Murray, Dinah. (2006). Coming Out Asperger: Diagnosis, Disclosure, and SelfConfidence, London: Jessica Kingsley Publisher.

Nunan, David. (2004). Practical English Language Teaching. New York: McGraw-Hill Companies.

Part Hyesook \& Adam R.Lee. (2004). L2 Learner's Anxiety, Self Confidence, and Oral Performance. Kunsan National University: Concordia University.

Rowson, Pauline. (2005). Communicating with More Confidence. England: Rowmark Limited.

Sugiyono. (2015). Metode Penelitian Pendidikan Pendekatan Kuantitatif, Kualitatif, dan RED. Bandung: CV Alfabeta.

Ur, Penny. (1991). A Course in Language Teaching. New York: Cambridge University Press. 